\title{
Christian gacaca and Official gacaca in Post-genocide Rwanda
}

\author{
Philippe Denis \\ denis@ukzn.ac.za
}

\begin{abstract}
In October 1998, a think tank of the Rwandan state proposed the establishment of gacaca jurisdictions - popular courts charged with judging the people involved in the genocide against the Tutsi. Lesser known is the Christian gacaca, a conflict resolution mechanism, also inspired by the traditional gacaca, which was established during the same period by the Catholic Church of Rwanda as part of the synodal process leading to the celebration of the 2000 Year Jubilee. This essay describes, on the basis of archival documents and oral testimonies, the genesis of the Christian gacaca and examines how it related to the official gacaca. This pastoral initiative contributed to a relaxation of the tension between church and state that had marked the immediate aftermath of the genocide. The aim of the Christian gacaca was to bring about reconciliation in communities divided by the genocide, by bringing together victims and perpetrators. The task of the official gacaca was to judge and, if the guilt was established, to punish the authors of the genocide crimes. It was also, like in the Christian gacaca, to restore social harmony, but only through a judicial process.
\end{abstract}

Keywords: Rwanda, genocide, Catholic Church, synod, 2000 Year Jubilee, Christian gacaca, official gacaca, Nyakibanda Major Seminary, Urugwiro Village

\section{Introduction}

A considerable amount of scholarship has been dedicated to the gacaca courts, an innovative community-based jurisdiction charged with judging, throughout 


\section{Philippe Denis}

Rwanda, the people involved in the genocide against the Tutsi (eg. Vandeginste 1999; Digneffe \& Fierens 2003; Schabas 2005; Meierheinrich 2005; Dumas 2008; Ingelaere 2009; Clark 2010; Penal Reform International 2010; Wielinga \& Harris 2011; Bornkamm 2012). The first studies elaborated on the hope that this novel form of transitional justice represented for a country still deeply traumatized and divided. The latter ones, while recognizing the usefulness of the gacaca process, documented its shortcomings in terms of social cohesion and reconciliation.

When the Rwandan Patriotic Front (FPR) achieved the conquest of the country in mid-July 1994, bringing an end to the genocide while prompting the exodus of about two million of predominantly Hutu people to Tanzania, Burundi, and Zaire, the judicial system was in tatters. Revenge killings and arrests on simple denunciation were common. Gradually, the judicial system was restored. Random murders stopped and more people were imprisoned for crimes of genocide, some without documentation. Soon, more than 120,000 people were languishing in overcrowded and poorly managed jails (Kimonyo 2017:178). During August 1996, a law was enacted to regulate the prosecution of genocide-related offences through the country's courts of justice, but this measure proved to be insufficient. By June 1999, only 634 individuals had been judged (Vandeginste 1999:11). At that pace, it would have taken 200 years to judge them all!

It was in this context that the Rwandan government proposed the institution of gacaca courts, which were popular jurisdictions inspired by a traditional form of conflict resolution. The law establishing the gacaca jurisdictions, was adopted in January 2001 and a data collection phase was launched in June 2002, followed by a trial phase in selected sectors. This led to the constitution of a list of 818,564 suspects in 2006 (Digneffe \& Fierens 2003; National Service of Gacaca Courts 2012:87). Nearly 200,000 community members were trained as inyangamugayo (gacaca judges) (National Service of Gacaca Courts 2012:193). The trials took place between 2006 and 2010. Not all suspects appeared before a gacaca court. Among those who did, approximately 60,000 were freed after having confessed their participation in the genocide (Kimonyo 2017:238).

Often ignored in the scholarly literature on the gacaca jurisdictions is the fact that, alongside the process leading to the institution of the gacaca jurisdictions by the Rwandan state in 2001, another gacaca process, pioneered by the Catholic Church of Rwanda, the biggest church in the country, took 
place in the late 1990s. Also inspired by the traditional gacaca, it is known under the name of Christian gacaca or gacaca Nkristu. To our knowledge, only four authors, Alice Karekezi (2001), Paul Rutayisire (2014), Phil Clark (2010), and Benoît Guillou (2014), respectively Rwandan, Australian, and French, paid attention to this original Christian practice of conflict resolution.

Since the mid-1950s, Archbishop André Perraudin, the main figure of the Catholic Church at the time, and the majority of the missionaries, had put all their weight in favor of the Hutu cause and, after the declaration of independence in 1962, provided full moral and logistical support to the Hutuled governments of Grégoire Kayibanda and Juvénal Habyarimana (Linden 1999; Carney 2014). They uncritically adopted the essentialist discourse describing the Hutu as perennial victims and the Tutsi, even those who were poor, as natural oppressors, unwittingly preparing the ground for the ideology of the genocide in 1994. When an army of Tutsi refugees attacked Rwanda under the banner of the FPR in October 1990, the Catholic Church rallied around President Habyarimana, only mildly protesting against the massacres of Tutsi civilians perpetrated by the Rwandan army in Kigali, in the western districts, and in the Bugesera in retaliation (Gatwa 2005; Longman 2010).

Following the shooting down of President Habyarimana's plane on 6 April 1994, the Hutu militia known as Interahamwe, with the active participation of the population and the logistical support of the police, the army, and the local government officials, started to systematically exterminate the Tutsi population, accused of siding with the FPR. An estimated 800,000 mostly Tutsi people, including children, women, and elderly people, were slaughtered in only three months. As late as July 1994, when the FPR finally defeated the interim government's army, the religious leaders, Catholic as well as Protestant, were still reluctant to acknowledge the reality of the genocide, claiming that it was a war between two armies and that their role consisted in providing mediation between the belligerents. Many Hutu priests and religious sisters saved Tutsi lives, but many more remained silent. Some adhered to the anti-Tutsi hysteria and assisted the killers in an active or passive way (Gatwa 2005; Rutayisire 2014).

After the genocide, when decomposed bodies were still lying around, part of the clergy and the faithful recognized their collective responsibility in the disaster, made plans to reconstruct the church on a new basis, and created spaces for a conversation between survivors and perpetrators or their families. Another part of the church, among missionaries, in the refugee camps in Zaire 


\section{Philippe Denis}

and in the Roman delegation in particular, continued to deny or minimize the genocide against the Tutsi, putting all the blame on the FPR. They used the fact, attested though not well documented and in some instances exaggerated, that, in the aftermath of the genocide, war crimes had been perpetrated against Hutu civilians by the Tutsi-led army, to develop the theory of a 'double genocide' (Denis 2018:301).

The relations between the new Rwandan government and the Catholic Church, or at least the sections of the church opposed to the FPR, became strained as a result. It was against this background that some Catholics imagined to promote the revival of the traditional gacaca in the interest of reconciliation. This initiative, alongside other forms of support to the reconstruction of the country, contributed to a reduction of the tension between the Catholic Church and the Rwandan state in the late 1990s.

This essay describes, on the basis of archival documents and oral testimonies, the genesis of the Christian gacaca and examines how it related to the official gacaca. It shows that both institutions developed in parallel and influenced each other until the official gacaca took a legal form and started to be put in place. The promoters of the Christian gacaca supported the establishment of gacaca jurisdictions by the state, while highlighting after a while their shortcomings and their limitations.

\section{Restoring the traditional gacaca}

By the time the genocide broke out in April 1994, the gacaca already existed in Rwanda but, as Rwandan lawyer Charles Ntampaka (1995) pointed out, it had already evolved. The term ' gacaca' means grass in Kinyarwanda. Traditionally, the gacaca was an informal and temporary open-air procedure of conflict resolution between members of the same lineage or of different lineages. All the male members of the concerned community were present. The aim of the process was reconciliation. There was no reference to a code of law. Only petty crimes and property issues were debated, not blood crimes. Similar conflict resolution mechanisms existed under different names in other African countries, including South Africa (Ntampaka 1995:104).

The gacaca that Belgian political scientist, Filip Reyntjens, describes in a 1990 article on the basis of fieldwork conducted in the Butare area in the late 1980 s, was already a transformed gacaca. It was an institution used by the 
families and the local authorities to arbitrate minor conflicts before referring them to a higher court if no agreement could be reached. The district tribunal served as appeal court (Reyntjens 1990). By contrast, the traditional gacaca had nothing to do with a centralized state-sponsored judicial system.

The first to envisage the possibility of resorting to the traditional gacaca in dealing with genocide crimes was Tito Rutaremara, one of the founders of the FPR and its president from 1987 to 1993. A member of the Rwandese Alliance for National Unity, a movement of Tutsi refugees established in Nairobi in 1979 that had morphed during December 1987 into the more radical and effective FPR, he had been exposed, during a stay in Paris, to the Marxist concept of popular insurgency as practiced, for example, in Latin America (Kimonyo 2017:113). This made him believe that popular courts could play a role in the situation Rwanda was experiencing after the genocide.

When Pasteur Bizimungu, the president of the FPR, asked him to find a way of dealing with the perpetrators of the genocide (as he explained to the American scholar, Jens Meierheinrich, in an interview), he suggested the restoration of the gacaca (Meierheinrich 2005:11). At his instigation, the action plan of the Ministry of Justice, which was adopted on 20 August 1994, recommended in its article 13 to 'restore the institution of the agacaca for the peaceful settlement of conflicts' (Vandeginste 1999:270-271; cf. Ntampaka 1995:95).

These discussions took place at Urugwiro Village, the president's residence in Kigali. At one of the meetings, Jyoni wa Karega, an intellectual who had fled to Zaire in the 1960s at the time of the anti-Tutsi pogroms and become a professor of history there before returning to Rwanda after the genocide, was asked to collect documentation on the traditional gacaca. $\mathrm{He}$ had just been appointed dean of the Faculty of Arts at the University of Butare, which was in the process of reconstructing itself after the loss of lives and property endured during the genocide (wa Karega 2018).

\section{The dean and the priest}

For this project, wa Karega received the support of the United Nations High Commissioner for Refugees, the Swiss Development Agency, the United States Agency for International Development, and Oxfam Quebec (Gacaca 1996a; Gacaca 1996b). His first task was to constitute a research team. He 


\section{Philippe Denis}

approached four university colleagues, Deogratias Byanafashe, Aloys Muberanziza, Jean-Chrysostome Munymapirwa, and Jean-Chrysostome Njehabahizi, two members of the Scientific and Technological Research Institute, Philbert Kagabo and Ladislas Twahirwa, as well as Smaragde Mbonyintege, a professor of theology at the Catholic Major Seminary of Nyakibanda, who was appointed rector of the seminary a year later and bishop of Kabgayi in 2006. Nyakibanda was a short distance from Butare. The dean and the rector, both men of letters, used to socialize in the university town (wa Karega 2018). Mbonyintege was released from his teaching duties to dedicate himself to the project. He used seminary students as research assistants (Mbonyintege 2016).

This is how, at a critical moment of Rwanda's history, a partnership was established between the National University of Rwanda in Butare, an institution with close links to the new Rwandan government, and the Major Seminary of Nyakibanda. All team members were tasked to investigate a certain sector, including Mbonyintege who conducted research in the area close to the seminary. Jyoni wa Karega and his colleagues presented the preliminary results of the research at a meeting held in Kigali on 13 July 1995. The report of the first phase was published in January 1996 and that of the second phase in June of the same year (Gacaca 1996a; Gacaca 1996b). Tito Rutaremara attended the presentation of the final report. According to Mbonyintege, he engaged vigorously but sympathetically with the findings of the study (Mbonyintege 2016).

By then, the Rwandan government had not yet decided to initiate a gacaca process in the country, but the idea was in the air. In November 1995, Philbert Kagabo, a member of wa Karega's team, had introduced the idea of the gacaca at the International Genocide Conference in Kigali. Four priests, including Mbonyintege, were among the 165 attendees. The agreement was that the genocide perpetrators could not simply receive amnesty, as in South Africa, for example. New forms of retribution had to be found. The conference resolved that in cases not involving crime against the person, customary Rwandan procedures such as the AGACACA [should] be used, or adapted, to the extent possible' (Recommendations 1995:art. 18; cf. Schabas 2005:6; Bornkamm 2012:25).

The research report of wa Karega and his colleagues revealed that, in the aftermath of the genocide, the gacaca method of conflict resolution had already been experimented with or at least proposed in various parts of the 
country. Philbert Kagabo, for example, described how a Conseil des Sages (Wisemen Council) had been instituted in Kigombe, in the Ruhengeri prefecture, to deal with land disputes and marital conflicts (Gacaca 1996a:2930). The report of the second phase of the project showed that various forms of gacaca, with or without links to the local authorities and the tribunals, had been mooted in the Kigali, Butare, Gitarama, Nyamata, Kibungo, Gikongoro, Cyangugu, and Byumba areas (Gacaca 1996b). In all these places the informants, whether private citizens or public officials, had some knowledge of the traditional gacaca.

Mbonyintege's summary report, which was included in the report of the first phase of the project, discussed 'the role that Gacaca could play in the reconciliation of Rwandans' (Mbonyintege 2016). He noted that the traditional gacaca facilitated reconciliation but did not allow impunity. He added that the current context made things difficult because the different individuals and factions developed an understanding of peace and reconciliation that fitted their particular interests. It was the task of the tribunals, and not of the gacaca, to judge the murders, rapes, and thefts committed during the genocide. Where the gacaca could help, was in establishing the truth and promoting the true values on which society could reconstruct itself. It did not help to put the Hutu on one side and the Tutsi on the other side. One should rather associate them in the task of reconstruction (Gacaca 1996b:35-37).

\section{The 2000 Year Jubilee}

The ideas expressed in this report found expression, three years later, in the Christian gacaca conducted in various sectors of the Catholic Church of Rwanda during the synodal process leading to the celebration of the Year 2000 Jubilee. Mbonyintege actively contributed to the popularization of the concept of gacaca in ecclesiastical circles. In August 1995, for example, he published in Urumuri rwa Kristu, the magazine of the Catholic diocese of Kabgayi, an article entitled How Gacaca can continue to be a tool of reconciliation for Rwandans (Mbonyintege 1995) that found readers not only in Rwanda but in the exile community in Europe (Ntampaka 1995:96). His promotion to the rectorship of the Nyakibanda Major Seminary in April 1996 (Guillaume 2011:51) increased his influence. 
In the Catholic Church, a Jubilee is a special year of forgiveness and reconciliation that is celebrated every 25 years throughout the world. The preparation for the 2000 Year Jubilee, which coincided with the advent of the third millennium, started in November 1994 with Pope John Paul II's apostolic letter, Tertio Millenio Adveniente, addressed to all bishops, priests, and lay people. In 2000, the Catholic Church was also to celebrate the arrival of the first missionaries in Rwanda in Save near modern-day Butare (or Huye as it was recently renamed), 100 years earlier. By the end of 1996, the social and political situation has stabilized enough for the Rwandan bishops to apply their minds to the preparation of this double jubilee. On 12 November, they issued a pastoral letter entitled Let us prepare the 2000 years of Christianity and the 100 years of the arrival of the Good News in Rwanda (Ngomazungu 2004:1314; Guillou 2014:124). By then, with the return of about 600,000 refugees to Rwanda after the dismantlement of the camps in Zaire, the polarization between the Rwandans in exile and those remaining in the country was subsiding. The country was moving forward despite a guerrilla warfare in the northwest. Gradually a modus vivendi between the Rwandan state and the Catholic Church was accepted. The time had come for the church as an institution to recognize the reality of the genocide.

The 2000 Year Jubilee, which could have easily become a non-event as in other countries in the world, became the occasion for the Catholic Church of Rwanda to initiate a process of self-reflection and mutual sharing on the genocide against the Tutsi. Until then, only the most progressive sectors of the Catholic Church had the courage to look at its moral responsibility in the genocide and to examine how the work of evangelization could be reestablished on a new basis. The church leadership was reluctant to admit its close association with the former regime and its blindness to the causes of the massacres. They were putting all the emphasis on the Hutu priests and lay people, fairly numerous indeed, who had risked their lives to protect the Tutsi. Many, including missionaries, in the clergy and at the nunciature, lived in denial, using their energy to denounce the failures and shortcomings, admittedly very real, of the new government (Denis 2018). Thanks to the insights of priests, such as Mbonyintege and Modeste Mungwarareba, the newly-appointed general secretary of the bishops' conference, or bishops like Frédéric Rubwejanga in Kibungo, the idea started to gain currency that it did not make sense to celebrate the Jubilee without looking back at what had happened in the country and in the church in 1994. 


\section{Two parallel trajectories}

As noted above, it was at Urugwiro Village that the idea of restoring the traditional gacaca with a view of dealing with the crimes of the genocide was first mooted in August 1994. In 1995, Mbonyintege, a priest and a theologian, was co-opted into a state-driven research project, spearheaded by wa Karega, a professor at the National University of Rwanda, and some of his colleagues. By then, private citizens and public officials had already started talking about the gacaca in their local communities.

In the end, the government did not follow the recommendations of wa Karega's report which were to rehabilitate the traditional gacaca institution (Gacaca 1996a:20). Instead, in 1998 and in subsequent years, it started to promote a modernized form of the gacaca court which, unlike the traditional gacaca, would have the power to sentence people to jail.

Meanwhile, the vision of a gacaca process aiming at reconciling and not sanctioning the people involved in the genocide continued its trajectory in the church and not in the state. If Mbonyintege had not been invited to take part in wa Karega's research, he probably would not have become, as he did, the advocate of a gacaca-type of process in the church. He did so, however, and independently from the state. The two trajectories ran concurrently but separately.

To understand this, the chronology needs attention. In May 1998, the government initiated a process that would lead to the adoption of the organic law, establishing the gacaca in January 2001. In July of the same year, 100 priests and four bishops proposed, at a meeting held in Nyakibanda Major Seminary, that all Rwandan dioceses should hold an extraordinary synod on the theme of ethnocentrism as a way of preparing for the 2000 Year Jubilee. This paved the way for the organization of the Christian gacaca processes throughout the country during the following year.

\section{The official gacaca}

From May 1998 to March 1999, civil society representatives and people close to the government met at Urugwiro Village on a weekly basis to discuss the problems facing the country. One of these was prison overcrowding. On 17 October 1998, they recommended the establishment of a commission to look into mechanisms that might increase popular involvement in the judicial 


\section{Philippe Denis}

proceedings against suspected genocide perpetrators (Vandeginste 1999:1; Bornkamm 2012:25; Kimonyo 2017:217-218). This new form of jurisdiction would be like the traditional gacaca with the difference that it would have the power to administer justice. The gacaca would become the arm of the state's judicial power at local level. Its reconciliatory function was not abandoned, since it gave victims and perpetrators the occasion to talk to each other, but it no longer was the main feature of the institution, as in the traditional gacaca.

In February 1999, Jean de Dieu Mucyo became the minister of justice and institutional relations. He became the main champion and organizer of the official gacaca. Another supporter of the gacaca at the time was Tito Rutaremara, who had advocated its restoration as early as 1994. In a 2002 interview, he justified the need for gacaca jurisdictions as follows:

Rwanda is a poor country. The human rights in our prisons are nothing to brag about. The prisoners are suffering, but what is the alternative? We cannot let them out, but we cannot really keep them in now either. To follow the western trial process would take far too long time and therefore be a violation of the human rights itself. We had to do something (Norwegian Helsinki Committee 2002:13).

Following the Urugwiro Village consultation, the minister of justice instituted a commission of 15 members, which was asked to examine the feasibility of gacaca courts. On 8 June 1999, this commission submitted a report entitled Juridictions Gacaca dans les procès de génocide et des massacres qui ont eu lieu au Rwanda du $1^{\text {er }}$ octobre 1990 au 31 décembre 1994 (Gacaca jurisdictions in the trials of the genocide and the massacres which took place in Rwanda from 1 October 1990 to 31 December 1994). The proposal defined the powers of these 'popular' tribunals, their composition, their modus operandi, the conditions for their establishment, and their relationship with the existing laws and institutions (Vandeginste 1999:1). The organic law establishing the gacaca that was adopted in January 2001, followed most of the commission's proposals. 


\section{An extraordinary synod on ethnocentrism}

Meanwhile, in the Catholic Church of Rwanda, a meeting of 100 priests and four bishops held at Nyakibanda Major Seminary from 4 to 7 July 1998 recommended that an extraordinary synod on ethnocentrism should take place. There was, one should note, hesitation in the language. The pastoral texts of this period indiscriminately spoke of 'ethnocentrism', of 'ethnic racism' and of 'ethnism'. The third expression, which is widely used in Rwanda today, is the best to express the ideological nature of the essentialist discourse on Hutu and Tutsi identities that eventually led to the genocide against the Tutsi.

This was a real breakthrough. For the first time, a large Catholic body declared its willingness to confront the reality of ethnic division in church and society. The term 'genocide' was not used but it was in everybody's mind. In the Presbyterian Church, a similar process, though more radical, had happened two years earlier when the general synod of the church publicly expressed repentance for its failure to oppose or denounce the genocide and the massacres (Gatwa 2005:227-228).

At the Nyakibanda meeting, the gacaca was hailed as a methodology allowing the Christian community to come to terms with the tensions born of the genocide. The findings of the wa Karega research, in which Mbonyintege, by now rector of the seminary, had participated, were presented to the delegates (Rutayisire 2014:318). 'During this period of preparation for the Jubilee', a report announced, 'each diocese will organize a synod that will proceed to the analysis of the issue of ethnic racism (racisme ethnique) that prevents the church from moving forward' (Ihugurwa ry' abapadiri, 1998, 48, quoted in Rutayisire 2014:308). Another report quoted the declaration that 'priority should be given to the traditional gacaca...in the preparation of the Jubilee, that is, a space where different Christian representatives meet and tell the truth' (Kinyamateka, 1143, 1998, 2, quoted in Rutayisire 2014:308).

At a meeting of the National Commission for the Jubilee held on 25 August 1998, the Rwandan bishops formally accepted the recommendations of the Nyakibanda meeting. Three months later, they announced, in the fourth Jubilee preparatory letter, the celebration of 'an extraordinary synod on the ethnocentrism that has provoked the sclerosis of Rwandan society' (Ngomazungu 2004:21). They would resort, they added, 'to the traditional culture of gacaca. This culture aims at arbitrating divisions and conflicts, at punishing, counselling and reconciling' (Kinyamateka, 1507, 1999, quoted in Rutayisire 


\section{Philippe Denis}

2014:309). They exhorted the members of the church 'to have the courage to speak openly of the problem [of ethnocentrism] according to [their] understanding while taking the pain of listening to and taking into account the opinion of others' (Kinyamateka, 1507, 1999, quoted in Rutayisire 2014:309). 'What we want', they added, 'is to incite people to share the truth in a climate of dialogue, to support each other in the sufferings they have endured, to recreate trust and to seek solutions together with the many problems they are facing' (Kinyamateka, 1507, 1999, quoted in Rutayisire 2014:309).

The announcement of the extraordinary synod on ethnocentrism was well received in the church. Some sectors of the church had in fact anticipated the process agreed upon for the extraordinary synod. In the diocese of Butare, the Comité pour la relance de l'activité pastorale (Committee for the revival of pastoral activity, or CRAP) had spoken of the challenges facing the Rwandan society with unusual frankness in a series of 12 widely circulated typewritten bulletins issued between September 1994 and December 1995. The steering committee included Mungwarareba, who was to become the general secretary of the bishops' conference in 1996, the lay theologian, Laurien Ntezimana, and the vicar general of the diocese, Félicien Mubiligi (Diocèse catholique de Butare 1996). In the diocese of Nyundo, where 30 Tutsi priests and countless other people had been massacred during the first month of the genocide, the survivors had placed a board at the entrance of the cathedral in 1995 with the words: Ibuka - Ugaye - Usabe (Remember - Beware - Pray) (Rwakareke 2018). In 1997, Simon Gasibirege, a psychologist teaching at the National University of Rwanda in Butare, started to run sessions for priests and religious leaders that prefigured, in some way, the Christian gacaca of the later periods. In the Rilima parish, a genocide site in the Bugesera, southeast of Kigali, a form of gacaca had taken place during the course of 1998 (Kinyamateka, 1488, 1998, 6, quoted in Rutayisire 2014:308).

The idea of a synod on ethnocentrism also met with resistance. Jean Ndorimana, at the time vicar general of the diocese of Cyangugu, referred in an interview to a meeting of the National Commission of the Jubilee during which no consensus could be reached on the need to discuss the ethnic problem. In the end, the archbishop of Kigali, Thaddée Ntihinyurwa, arbitrated in favor of those who wanted an open discussion on this topic (Ndorimana 2018). Some wondered if the church was ready for a debate on ethnocentrism. 'Confronting the past', the editor of the Catholic newspaper, Kinyamateka, argued, 'is problematic for people who have to relate, in words or through their 
example, to people who are still under the shock of the Rwandan genocide and its consequences' (Kinyamateka, 1509, 1999, 6, quoted in Rutayisire 2004: 310). Félicien Mubiligi, the former vicar general of the Butare diocese, was skeptical about the church's readiness to embark on such an ambitious process: 'We react to things as they come', he wrote in a church magazine, 'and we respond to emergencies, often satisfying ourselves with patching up holes. Fundamentally, we remain immobile precisely because of the paralysis that is affecting us' (Ihugurwa ry' abapadiri, 1998, 37, quoted in Rutayisire 2014: 311).

\section{A diversity of responses}

The synodal process opened in the diocese of Butare on 5 September 1998 two months before the bishops ratified the choice of ethnocentrism as a theme for the extraordinary synod. The diocese of Kibungo followed on 6 December 1998. The dioceses of Nyundo and Ruhengeri, in Northwest Rwanda, delayed the opening of the synod because of the guerrilla war waged by the former Interahamwe forces in this part of the country. In the diocese of Gikongoro, the process came to a halt in April 1999, when the bishop, Augustin Misago, was put in jail for his alleged participation in the genocide. He was cleared by a court, 14 months later. Training sessions took place in most dioceses, facilitated by experts such as Simon Gasibirege. The process ended with a synodal assembly bringing together clergy and laity (Commission Épiscopale du Clergé 2000).

Paul Rutayisire noted the diversity of approach to the synod in the nine dioceses of Rwanda. In his opinion, only three of them - Kigali, Cyangugu, and Nyundo - seriously tackled the issue of ethnism and made use of the gacaca methodology in a consistent way. In the Kabgayi diocese, ethnocentrism was only one theme, the others being family and education. The same applied to the Butare diocese. In dealing with the consequences of the genocide, the diocese of Kibungo tended to take a spiritualizing approach (Commission Épiscopale du Clergé 2000; Rutayisire 2014:315).

In all dioceses, except that of Ruhengeri, because of the insecurity reigning there at the time, the synod started with a solemn Mass celebrated by the bishop with all his priests. The objectives of the synod were then explained to the participants: 'Of all the problems faced by the Church', Anastase 


\section{Philippe Denis}

Mutabazi, the bishop of Kabgayi, declared, 'that of ethnism goes on for ever and is at the root of all other problems. We cannot relax and prepare the Jubilee while our society is eaten up by mistrust, suspicion, contempt, vengeance, all feelings that are dictated by ethnic differences' (Rutayisire 2014:312).

In all the dioceses, structures were put in place to steer the synodal process. The first step was to organize assemblies during which experts and other resource individuals would give input on topics such as the history of Rwanda, traumatism, healing, reconciliation, non-violence, and human rights. The movement then trickled down to the parish level with the assistance of 'synod facilitators' (abakangurambaga ba sinodi). Audiences such as school learners, religious communities, prisoners, intellectuals, and families were targeted (Rutayisire 2014:315).

In the dioceses that chose to follow the gacaca methodology, the participants were encouraged to confess their sins to the congregation and ask for forgiveness from the people they had wronged. This applied to genociderelated crimes as well as minor offenses. Forgiveness was the key. In a report published in 2003, Alice Karekezi observed that 'embedded in the Christian gacaca is the notion that, once an individual has confessed certain sins, it is the "divine obligation" of those personally offended or the general congregation to forgive the sinner' (Karekezi 2001:34; Clark 2010:66). Stories of reconciliation in the communities, having practiced the Christian gacaca, are not rare. They only concern, however, a relatively small number of genocide crimes.

\section{The Christian gacaca in Kigali}

More than any other, the diocese of Kigali devoted itself to following the gacaca methodology. Emmanuel Ngiruwonsanga, a seminarian at the time, described the process followed there between February 1999 and December 2001 in a MA thesis defended in 2013 in Canada. He was part of the team of trained facilitators:

The synod began with a solid preparation of the trainers who would lead the Christians in their BEC [Basic Ecclesial Community]. The synod process was also conducted in the prisons where those accused 
of genocide were kept. It was in this context as a candidate priest that I too was trained in order to train the others (Ngiruwonsanga 2013:98).

There were two parts in the synodal process - one centered on mutual sharing and the other one on forgiveness. The gacaca methodology was used to encourage people to speak out:

The process was divided into two periods, and the first consisted in isanamutima - rebuilding of humanness - which consisted of rebuilding the dignity, confidence and the true image of the human person as willed by God...In order to succeed in this job through the synod, participants were invited to freely open their hearts and minds and let flow out everything that wants out. But this was only done in small teams called itsinda ry'ubuzima, life teams, where anything said there would remain secret among the members of the same group until the one who gives the testimony would make the decision to share it in the larger team (Ngiruwonsanga 2013:98, 99).

Then came a moment of forgiveness and reconciliation:

The second process was pardon and reconciliation... Thanks to the first process they were many who were ready to forgive anyone who would confess what he had done; or, to take the first step and offer forgiveness to those they knew had harmed them regardless of whether he had asked to be forgiven or not. The height of this process was the reconciliation of one with oneself, as everything that kept him slave of himself had been given away (Ngiruwonsanga 2013:99, 100).

At the conclusion of the synod, some victims, perpetrators, and witnesses agreed to testify publicly. Ngiruwonsanga reproduced a few testimonies in his thesis:

To sum up this process and the peace and joy it brought to people who followed the synod, let us take a look at some testimonies made public during the closure of the synod. These are divided into three categories: the victims who freely forgave their offenders; the executioners who asked to be forgiven and accepted to pay whatever they would be 
charged with (including death or jail); those who had accused their neighbours and public justice had sent them to jail (Ngiruwonsanga 2013:101).

Another source of information on the synod and the Christian gacaca is the survey commissioned by the Archdiocese of Kigali during late 2001. The respondents acknowledged with remarkable frankness the depth of ethnic divisions in the Christian community. When relating to neighbors, they explained, they would always consider to which ethnic group they belonged. They admitted to having badly behaved during the war and the genocide, 'because of feelings of anger, hatred, rancour, jealousy and mistrust' (Archidiocèse de Kigali 2001:6, 8, quoted in Rutayisire 2004:316).

Several groups declared that the Christian community had abandoned the people during the genocide and the massacres because they had done nothing to save them except in a few individual cases. Many said that they had behaved in that way 'because of fear because they also were terribly threatened by the murderers' (Archidiocèse de Kigali 2001:17, quoted in Rutayisire 2004:317). None of them had killed at the request of the church. However, 'the passivity towards the genocide showed that most Christians did not have a lived and committed faith' (Archidiocèse de Kigali 2001:17, quoted in Rutayisire 2004:317).

\section{The charismatic movement's reappropriation of the traditional gacaca}

Unsurprisingly, the themes of forgiveness and reconciliation struck a chord with the Catholic Charismatic Movement, which saw in them a sign of the Spirit. In Rwanda, its most prominent representative was the Emmanuel Community. Established in 1990 by a Catholic couple, Cyprien Rugamba and Daphnose Mukansanga, the Community had known a rapid development, soon interrupted by the genocide, which cost the lives of ten of the 40 or so initial members, including the two founders. Quite a few fled to Zaire in July 1994 and some have died in the forest after the dismantlement of the refugee camps in late 1996. The ethnic divisions that the genocide had exacerbated, affected the Community as it did the rest of the Catholic Church. This did not prevent them, however, from doing reconciliation work between the Hutu and Tutsi 
after the genocide, in Nyamata, in the Bugesera, for example (De Kempe \& Moens 1995).

The Emmanuel Community, which is a lay movement with priests as associates but not directors, is doing evangelization work in close partnership with the local hierarchies. In Rwanda, it heeded the November 1998 bishops' call to prepare the Jubilee with an extraordinary synod on ethnocentrism. The church decided, 'not without questions and fears', a report noted (Moens 2000), to apply the gacaca methodology to themselves. Several meetings prepared a general assembly in July 1998 that paved the way to a gacaca process in four steps in all the areas where the Community had members. A final assembly closed the cycle.

The Emmanuel Community developed its own interpretation of the gacaca in line with its spiritual tradition:

It was clear that the objective of the Gacaca was not to seek culprits but rather to show how each one lived this situation. It consisted in hearing the teachings [of the Community] and taking part in adoration [of the Holy Sacrament] and on that basis looking at one's situation and sharing it with others, as one decided, as one wanted, in truth, as much as one felt comfortable with and in all freedom. The wise men of the traditional Gacaca had been replaced by Jesus, and the grass by the adoration. This changed the entire perspective. It was about exposing oneself to the mercy of Jesus... Understood like this, the Gacaca could be a way of reconciling with oneself, with God, with the other (Moens 2000).

This methodology and this spirituality had repercussions beyond the Emmanuel Community, in particular in the southeastern diocese of Cyangugu. Ubald Rugirangoga, a Tutsi priest who had tried, in vain, to prevent a massacre of refugees in his parish of Nyamasheke during the genocide before fleeing to Cyangugu and from there to Bukavu, became, in 1998, the secretary of the synod in the diocese of Cyangugu, while serving in the Mushaka parish, where he had been sent in the meantime. He had close links with the Emmanuel Community. Like most survivors, he had lost many family members to the genocide. While still in Nyamasheke in the early 1990s, he had started, rather discreetly, a healing ministry that he developed later in Mushaka and other areas. 


\section{Philippe Denis}

In a document he subsequently posted on his website, Rugirangoga described his experience of the Christian gacaca in the following terms:

I helped my parishioners to do a good synod. They openly exchanged views, debated on the problems they were facing and came to the conclusion that being part of an ethnic group was not a problem. The ethnic ideology was a political creation to manipulate the population. Our task was to help the Christians to get out of this ideology by describing to them how the genocide against the Tutsi had been effected in the parish (Rugirangoga 2013:2).

Later on, when the official gacaca was in full swing, Rugirangoga imagined a process that resembled, in some way, that of the Emmanuel Community. It consisted in organizing, according to a set schedule, separate recollections for the genocide survivors and for the people or their relatives accused of having been involved in the genocide, with a view to helping them to reconcile privately or in public, if they chose to do so. The process culminated in a 'feast of reconciliation' associating both groups a few weeks later (Rugirangoga 2013:4). Subsequently, Rugirangoga organized recollections for a third group, the Hutu, who had witnessed the genocide and tried to give support to the Tutsi, threatened of extermination.

In the same document, he explained that he had developed this method to 'calm the spirits' of his parishioners during the gacaca period:

On the eve of the Gacaca trials, the convicts suspected of having perpetrated the genocide who admitted their sin were liberated in big numbers. This created a panic among the victims of the genocide against the Tutsi. Terrified, they confided to me who was their priest, they felt threatened, they thought that the genocidaires who had been liberated in big numbers would kill them because no witness of the genocide against the Tutsi should survive. This incited me to organise the recollections in order to calm the spirits (Rugirangoga 2013:2). 


\section{The celebration of the Jubilee}

The Christian gacaca cannot be disassociated from the extraordinary synod on ethnocentrism held in preparation for the 2000 Year Jubilee. The manner in which the Jubilee was celebrated at the end of the process, in February 2000, reflected the spirit that reigned during the Christian gacaca sessions.

During the Jubilee celebration in Save, the site of the oldest Catholic mission station in Rwanda, the Catholic bishops made a first step towards a full confession of guilt. The Rwandan president, Pasteur Bizimungu, and other dignitaries were present. In a prayer addressed to God - not to the victims, explicitly at least - the bishops asked forgiveness for 'those who prepared and executed the genocide and the massacres, who deliberately shed the blood of others, who killed by vengeance, who blindly followed orders and who could not discern what was contrary to the Gospel' (Kinyamateka, 1546, February 2000:7, quoted in Denis 2017:15). They also asked forgiveness for the priests and religious leaders 'who, in moments of division, failed to be credible signs of unity and communion', for the political leaders 'who neglected their duty' and for the religious leaders 'who did not have any discernment in their relations with the powerful' (Kinyamateka, 1546, February 2000:7, quoted in Denis 2017:15).

Several bishops made a confession of guilt in their individual capacity during the Jubilee celebrations. The bishop of Byumba, Servilien Nzakamwita, was particularly outspoken: 'As we celebrate the Jubilee of Evangelization', he said, 'we feel ashamed to see that more than half of the Rwandan population that claimed to be Christian could not stop nor avoid the brutalities of the genocide and of the massacres perpetrated in this country'. Bishop Rubwejanga from Kibungo wondered, at a celebration held in Kabgayi, if the leaders of the church should not ask themselves if they had not committed 'faults similar to those for which God blamed the pastors from olden times'. He asked for forgiveness in his capacity as a pastor: 'We asked for forgiveness', he said, 'for the sins committed by the priests in the care of the souls that God had entrusted to them' (Bulletin de la Conférence Épiscopale du Rwanda, 13-17, 1999-2000, 37, quoted in Rutayisire 2014:322).

As Rutayisire (2014:323) pointed out, these confessions of guilt have not been widely publicized. Among the genocide survivors and in government circles, they were deemed insufficient. The Catholic Church, they said, only acknowledged the involvement of certain of its members in the genocide 


\section{Philippe Denis}

against the Tutsi and not that of the institution itself. The church did not recognize its role in the spreading of the ethnic stereotypes that contributed to the eruption of the genocide in April 1994.

This may be true. It remains that the attitude of repentance showed by the Catholic leadership during the Jubilee celebrations was a significant departure from the attitude of defensiveness and quasi-denial adopted by many church leaders and priests in the period immediately following the genocide. Quite a few Catholics, one should remember, had been feeding the ongoing discourse on the double genocide, which de facto trivialized the genocide against the Tutsi and made it almost acceptable. There is no doubt that the Christian gacaca contributed to the change of heart, at least to a certain degree, of the Catholic leadership. This extended process of sharing of experience and of research of the truth during the Christian gacaca led to the recognition that the church had to be more overt about its responsibility for the tragedy.

\section{Christian gacaca versus official gacaca?}

As discussed above, the decision to promote the Christian gacaca to prepare for the Jubilee and the decision to establish the official gacaca to resolve the problem of prison overcrowding were made during the same period, the first at a meeting held in Nyakibanda in July 1998 and the second at the Urugwiro Village in October 1998. When the news filtered through that the Catholics were organizing gacaca sessions, many people, including congregants, were wondering if the church was not competing with the state in matters of genocide retribution.

The two institutions indeed had different aims. The aim of the Christian gacaca was to promote reconciliation in communities divided by the genocide by bringing together victims and perpetrators. That of the official gacaca was to judge and, if the guilt was established, to punish the authors of the genocide crimes. It was also, like in the Christian gacaca, to restore social harmony, but only by way of a judicial process. How could these two forms of conflict resolution cohabit? As the Catholic newspaper, Kinyamateka, reported, some people were saying that the gacaca of the church hampered the state gacaca, because the church did not incriminate anybody and was not authorized to punish (Kinyamateka, 1539, 1999, 6, quoted in Rutayisire 2014: 313). 
By then, fortunately, channels of communication existed between the Catholic Church and the Rwandan government. Various meetings helped to clarify the misunderstandings. In October 1999, representatives of the bishops' conference were given the opportunity to explain their position to Patrick Mazimhaka, the minister at the presidency. 'The bishops', they told him, 'want to say that the Christian gacaca is not a new instance of justice but the opportunity to get groups of Christians to debate on questions related to the life of the church as a whole and on the relations they have among themselves' (Kinyamateka, 1539, 1999, 6, quoted in Rutayisire 2014:313).

The National Commission for Unity and Reconciliation, a body created in March 1999 to promote reconciliation among Rwandans, also addressed the misgivings about the role of the Christian gacaca. One of its tasks was to prepare the ground for the establishment of the gacaca. The Commission held consultations with various civil society organizations, including religious denominations (Commission of Unity and Reconciliation 2000:29). During the course of the year, the president of the Commission, JeanNépomuscène Nayinzira, a former Cabinet minister, came to a synodal meeting in Kigali at which Archbishop Ntihinyurwa was present. He echoed the government's concern that the Christian gacaca 'aim[ed] at uniting and reconciling but forg[o]t the objective of punishing' (Kinyamateka, 1534, 1999, 2 , quoted in Rutayisire 2014:314). The archbishop responded that crime repression was the responsibility of the state and not of the church, arguing: 'The church does not replace the instances responsible for punishment. It encourages people to confess and ask for forgiveness so that love returns to the place from where it had disappeared. The church is careful not to hamper the work of justice' (Kinyamateka , 1534, 1999, 2, quoted in Rutayisire 2014:314).

\section{The bishops' letters on the gacaca}

This work of explanation paid dividends. Gradually the confusion dissipated. In any event, the time of the Christian gacaca ended after the Jubilee. Forums where survivors, perpetrators, and other people involved in the genocide carried on afterwards, as in the diocese of Cyangugu, were without the name of Christian gacaca.

The Justice and Peace Commission of the Bishops' Conference pursued the work of reconciliation after the closure of the extraordinary synod on 


\section{Philippe Denis}

ethnocentrism. They continued to engage, sometimes vigorously, with the government. Paul Rutayisire mentioned, in an interview, a discussion between Jean de Dieu Mucyo, the minister of Justice, and the members of the Commission a year or two after the adoption of the law establishing the gacaca. The debate was on whether or not family members should be compelled by law to denounce relatives who had been involved in the genocide (Rutayisire 2018).

The Rwandan bishops issued two pastoral letters on the gacaca jurisdictions - in June 2002 and in March 2006. Entitled For a justice that reconciles, the first welcomed the government's decision to institute the gacaca jurisdiction and formulated the hope that this instrument would speed up the work of justice. It also expressed concerns: Would not life become impossible in the villages if neighbors denounced neighbors and family members other family members? The bishops took, however, a positive approach and encouraged the faithful to tell the truth. The only exception concerned the priests, who had received the interdiction, under pain of excommunication, of violating the secret of confession (Conférence Épiscopale du Rwanda 2002).

The second letter was published in February 2006, shortly before the gacaca program started to be implemented countrywide. This Message of the Catholic bishops of Rwanda urging Christians to take an active part in the gacaca jurisdictions pointed out the positive results achieved so far, with many victims having found relief after the truth was established and many perpetrators having asked for forgiveness. The bishops warned, however, against the risk of false testimonies and instrumentalization of the gacaca courts by private interests. As they did in their first pastoral letter, they encouraged the faithful to tell the truth in all circumstances (Conférence Épiscopale du Rwanda 2006).

By law, observers were allowed to attend the hearings. Between April and May 2007, the Justice and Peace Commission of the Bishops' Conference trained 486 observers (Gasana 2008). The majority of them received an observer's permit and were dispatched in the dioceses. They provided a balanced assessment of the gacaca process. According to them, many judges were conscientious and fair, the witnesses felt safe, and there were very few cases of retraumatization. There were instances, however, of corruption, of intimidation of witnesses and of false testimonies (Gasana 2008). The final report, compiled in April 2008, did not venture to give an estimate of the 
proportion of judgments that, in the opinion of the Justice and Peace Commission, appeared unfair. Penal Reform International, a British nongovernmental organization, reached similar conclusions in a report published in 2010, but they insisted, more than the Justice and Peace Commission, on the insufficiency of the rights of the defense (Penal Reform International 2010).

\section{Conclusion}

The history of the Christian gacaca is interesting for two reasons. First, it throws new light on the attitude of the Catholic Church of Rwanda, which has been accused of having indirectly contributed, through its proximity to the Habyarimana regime and through its silence during the massacres to the genocide against the Tutsi. In the immediate aftermath of the genocide, many church leaders did indeed deny or minimize their responsibility. Making full use of the traditional gacaca model as popularized by Mbonyintege, a member of the research team gathered by wa Karega in 1995, however, the church leadership used the opportunity of the 2000 Year Jubilee celebration to launch in all Rwandan dioceses a synodal process focused on the ethnic question. In the process, they made use of the Christian gacaca methodology, an innovative conflict resolution instrument for a society deeply traumatized by the genocide.

This study also reveals the existence of an insufficiently known form of cooperation between church and state in Rwanda. In the late 1990s, the tension between the Catholic hierarchy and the new regime that had marked the aftermath of the genocide left way to new forms of accommodation.

The official gacaca and the Christian gacaca had the same sources: The traditional gacaca, to which Tito Rutaremara, one of the founders of the Rwandan Patriotic Front, referred to as early as August 1994, a month after the end of the genocide. The state and the church initially cooperated in wa Karega's research project, but then followed separate trajectories. The church imagined a process, exclusively focusing on reconciliation and social harmony reconstruction, like in the traditional gacaca, while the state used the gacaca model to develop a form of popular justice capable of judging the enormous quantity of genocide suspects languishing in prison and other people suspected of having being involved in the massacres.

This could have led to a conflict between the state and the church, but it did not. The bishops praised the establishment of the official gacaca in two 
pastoral letters, issued in 2002 and 2006 respectively, while keeping the liberty of highlighting its shortcomings when they became apparent, as a monitoring report of the Episcopal Justice and Peace Commission published in 2008 made it clear (Gasana 2008). The gacaca certainly had weaknesses, but without it, social relations in Rwanda would have been much worse than they are today.

\section{References}

Archidiocèse de Kigali. 2001. Célébrons le synode: Je n'oublierai jamais que tu es mon frère. Kigali: Archidiocèse de Kigali.

Bornkamm, P.C. 2012. Rwanda's gacaca courts: Between retribution and reparation. Oxford: Oxford University Press.

Carney, J.J. 2014. Rwanda before the genocide: Catholic politics and ethnic discourse in the late colonial era. New York: Oxford University Press.

Clark, P. 2010. The gacaca courts, post-genocide justice and reconciliation in Rwanda. Cambridge: Cambridge University Press.

Commission Épiscopale du Clergé. 2000. Évaluation du processus synodal: Actes de la session des prêtres, Nyakibanda du 28 Août - $1^{\text {er }}$ Septembre 2000. Kigali: Commission Épiscopale du Clergé.

Commission of Unity and Reconciliation. 2000. Rapport annuel des activités de la commission nationale pour l'unité et la réconciliation, période allant de mars 1999 à juin 2000. Kigali: Commission of Unity and Reconciliation.

Conférence Épiscopale du Rwanda. 2002. Pour une justice qui réconcilie. Kigali: Conférence Épiscopale du Rwanda.

Conférence Épiscopale du Rwanda. 2006. Message des évêques catholiques du Rwanda exhortant les chrétiens à prendre une part active aux juridictions gacaca. Kigali: Conférence Épiscopale du Rwanda.

De Kempe, K. \& J.-L. Moens 1995. Voyage au Rwanda, 2 juin - 17 juin 1995. Jean-Luc Moens, private papers.

Denis, P. 2017. Germany, South Africa and Rwanda: Three manners for a church to confess its guilt. Studia Historiae Ecclesiasticae 43, 2: 1-20.

Denis, P. 2018. Grief and denial among Rwandan Catholics in the aftermath of the genocide against the Tutsi. Archives des sciences sociales des religions 183, July-September: 287-307. 
Digneffe, F. \& J. Fierens (ed.) 2003. Justice et gacaca: L'expérience rwandaise et le génocide. Namur: Presses Universitaires de Namur.

Diocèse catholique de Butare. 1996. Fécondité de la crise rwandaise: Jalons pour une nouvelle évangélisation au Rwanda. Butare: Comité de Relance des Activités Pastorales.

Dumas, H. 2008. Histoire, justice et réconciliation au Rwanda: Les juridictions gacaca au Rwanda. Mouvements 53: 110-117.

Gacaca. 1996a. Gacaca. Le droit coutumier au Rwanda. Rapport final de la première phase d'enquête sur le terrain réalisé par les chercheurs de l'Université Nationale du Rwanda (UNR), de l'Institut de Recherche Scientifique et Technologique (IRST-Butare), du Grand Séminaire de Nyakibanda. Première phase du projet, Kigali 31.01.96. Kigali: Nations Unies, Haut-Commissaire aux Droits de l'Homme, Opération sur le terrain au Rwanda.

Gacaca. 1996b. Gacaca: Le droit coutumier au Rwanda. Rapport final de la deuxième phase d'enquête sur le terrain réalisé par les chercheurs de l'Université Nationale du Rwanda (UNR), de l'Institut de Recherche Scientifique et Technologique (IRST-Butare), du Grand Séminaire de Nyakibanda. Deuxième phase du projet, Kigali, 30.06.96. Kigali: Nations Unies, Haut-Commissaire aux Droits de l'Homme, Opération sur le terrain au Rwanda.

Gasana, V. 2008. Rapport synthétique du monitoring des juridictions gacaca. Kigali: Commission Justice et Paix de la Conférence Épiscopale du Rwanda.

Gatwa, T. 2005. The churches and ethnic ideology in the Rwandan crises 19001994. Milton Keynes: Regnum Books International.

Guillaume, A. (ed.) 2011. Histoire du Grand Séminaire Saint-Charles Borromée de Nyakibanda à l'occasion de son jubilé de diamant. Nyakibanda: Cercle Saint-Paul.

Guillou, B. 2014. Le pardon est-il durable? Une enquête au Rwanda. Paris: Éditions François Bourin.

Ingelaere, B. 2009. 'Does the truth pass across the fire without burning?' Locating the short circuit in Rwanda's gacaca courts. Journal of Modern African Studies 47: 507-528.

Karekezi, A. 2001. Juridictions gacaca: Lutte contre l'impunité et promotion de la réconciliation nationale. In Ntaganda, E. (ed.): Les juridictions 
gacaca et les processus de réconciliation nationale. Cahiers de Centre de Gestion des Conflits. Butare: Université Nationale du Rwanda.

Kimonyo, J.-P. 2017. Rwanda demain! Une longue marche vers la transformation. Paris: Karthala.

Linden, I. 1999. Christianismes et pouvoirs au Rwanda, 1900-1990. Paris: Karthala.

Longman, T. 2010. Christianity and genocide in Rwanda. Cambridge: Cambridge University Press.

Mbonyintege, S. 2016. Interview conducted by Philippe Denis in Kigali, 13 December 2016.

Meierheinrich, J. 2005. The invention of gacaca: A logic of institutional choice. Working paper. Available at: https://cddrl.fsi.stanford.edu/events/the political economy of lawfare. (Accessed on 9 February 2019.)

Moens, J.-L. 2000. Voyage au Rwanda, 3-7 janvier 2000. Jean-Luc Moens, private papers.

National Service of Gacaca Courts. 2012. Gacaca courts in Rwanda. Kigali: National Service of Gacaca Courts.

Ndorimana, J. 2018. Interview conducted by Philippe Denis in Huye, 23 May 2018.

Ngiruwonsanga, E. 2013. The shortcomings of capitalism and communism in light of John Paul II's 'humanness'. Unpublished MA thesis, Atlantic School of Theology, Halifax, Nova Scotia.

Ngomazungu, J. 2004. Messages et lettres pastorales des évêques catholiques pendant la période 1994-2004. Urunana. Revue des Grands Séminaristes 108: 4-30.

Norwegian Helsinki Committee. 2002. Prosecuting genocide in Rwanda: The gacaca system and the International Criminal Tribunal for Rwanda. Report II/2002. Oslo: The Norwegian Helsinki Committee.

Ntampaka, C. 1995. Le retour à la tradition dans le règlement des différends: Le gacaca du Rwanda. Dialogue 186: 95-105.

Penal Reform International. 2010. Huit ans après: Le point sur le monitoring de la Gacaca au Rwanda. London: Penal Reform International.

Recommendations. 1995. Recommendations of the conference held in Kigali from November $1^{\text {st }}$ to $5^{\text {th }}, 1995$ on 'Genocide, impunity and accountability: Dialogue for a national and international response'. Kigali: Office of the President. 
Reyntjens, F. 1990. Le gacaca ou la justice du gazon au Rwanda. Politique Africaine 40: 31-41.

Rugirangoga, U. 2013. Information sur la pastorale de pardon et réconciliation dans la paroisse MUSHAKA. Available at: https://frubald.files.wordpress.com/2013/04/information-sur-la-pastorale.pdf. (Accessed on 9 February 2019.)

Rutayisire, P. 2014. Le Catholicism Rwandais: Un regard interrogateur. In Gatwa, T. \& L. Rutinduka (eds): Histoire du christianisme au Rwanda. Yaoundé: Éditions CLÉ.

Rutayisire, P. 2018. Interview conducted by Philippe Denis in Kigali, 20 May 2018.

Rwakareke, F. 2018. Interview conducted by Philippe Denis in Nyundo, Western Province, 28 May 2018.

Schabas, W.A. 2005. Genocide trials and gacaca courts. Journal of International Criminal Justice 3: 1-17.

Vandeginste, S. 1999. Justice, reconciliation and reparation after genocide and crimes against humanity: The proposed establishment of popular gacaca tribunals in Rwanda. Paper read at the All-Africa Conference on African Principles of Conflict Resolution and Reconciliation United Nations Conference Centre, Addis Ababa, 8-12 November 1999.

wa Karega, J. 2018. Interview conducted by Philippe Denis in Kigali, 25 May 2018.

Wielinga, C. \& G. Harris 2011. Building peace and security after genocide: The contribution of the gacaca courts in Rwanda. African Security Review 20: 15-25.

Philippe Denis

History of Christianity Programme School of Religion, Philosophy and Classics University of KwaZulu-Natal denis@ukzn.ac.za 